\title{
A Retrospective Perinatal Data Analysis of Immigrant and German Women from Representative Birth Cohorts at the Virchow Hospital, Berlin
}

\author{
Perinataldaten von Migrantinnen und deutschen Frauen - eine retrospektive Auswertung repräsentativer \\ Geburtskohorten des Berliner Virchow-Klinikums
}

Authors

Affiliation

\section{R. Armbrust, R. von Rennenberg, M. David}

Charité - Universitätsmedizin Berlin, Campus Virchow-Klinikum, Klinik für Gynäkologie, Berlin, Germany
Key words

- immigration

- perinatal data

women of Turkish origin

Schlüsselwörter

- Migration

- Perintaldaten

○ türkeistämmige Frauen

Deutsche Version unter: http://dx.doi.org/ 10.1055/s-0042-111011 received 10.4.2016 revised 21.6.2016 accepted 22.6.2016

\section{Bibliography}

DOI http://dx.doi.org/ 10.1055/s-0042-111011 Geburtsh Frauenheilk 2016; 76 : 1157-1162 @ Georg Thieme Verlag KG Stuttgart · New York ISSN 0016-5751

\section{Correspondence}

\section{Dr. med. Robert Armbrust}

Campus Virchow Klinikum

Klinik für Gynäkologie

Charité - Universitätsmedizin

Berlin

Augustenburger Platz 1

13353 Berlin

Germany

robert.armbrust@charite.de

\section{Abstract \\ $\nabla$}

Introduction: The aim of this study was to define and characterise differences in the level of obstetric care provided to immigrant and German women.

Materials and Methods: An analysis of the Virchow Hospital's birth registers was conducted for the years 1974, 1984 and 1994. The study population of 5445 patients was grouped according to ancestry/family origin on the basis of a name analysis, and subsequently also according to parity (primiparous or multiparous). On name analysis 2741 women were defined as German, 1598 were grouped as women of Turkish origin and 810 as immigrants of other origin. $\mathrm{X}^{2}$ tests and Fisher's exact test were used for significance testing (significance level $\mathrm{p}<0.05$ ), and a logistic regression analysis was performed.

Results: Rates of caesarean section, episiotomy, higher grade perineal tears and severe postpartum haemorrhage did not differ between the groups. There were however significant differences in the use of uterine stimulants, analgesics in labour and both local and regional anaesthesia, with women of Turkish origin and other immigrants receiving anaesthesia less, but oxytocin more often. Rooming-in was more common among German primipara and multipara from 1984 onwards.

Discussion: This retrospective analysis of three historical birth cohorts showed significant differences in perinatal care between German and immigrant women, presumably reflecting deficits in care. It seems remarkable that this trend has not changed over a time span of three decades despite a continuous increase in immigration and acculturation. A "research paradox", however, remains: Despite these increasing rates, there are no current or older, prospective or systematic studies of obstetric care in immigrants.

\section{Zusammenfassung \\ $\nabla$}

Einleitung: Ziel der Studie ist, Unterschiede zwischen Migrantinnen und deutschen Frauen bez. des Versorgungsgrads während der Geburt herauszuarbeiten.

Material und Methodik: Es erfolgte eine Auswertung der Geburtenbücher des Virchow-Klinikums der Jahre 1974, 1984 und 1994. Die Studienpopulation von 5445 Patientinnen wurde anhand einer Namensanalyse nach Herkunft und anschließend nach Parität in Erst- und Mehrgebärende eingeteilt. Es wurden 2741 Patientinnen der Gruppe deutscher Frauen, 1598 den türkischen und 810 den Migrantinnen anderer Herkunft zugeordnet. Die Signifikanzprüfung erfolgte mittels des $X^{2}$ Tests bzw. des exakten Tests nach Fisher (Signifikanzniveau $\mathrm{p}<0,05$ ). Außerdem wurde eine logistische Regressionsanalyse durchgeführt.

Ergebnisse: Sowohl die Rate an abdominellen Schnittentbindungen, Episiotomien, höhergradigen Dammrissen als auch an schweren postpartalen Blutungen war zwischen den Kollektiven nicht unterschiedlich. Signifikante Unterschiede fanden sich allerdings bei der Rate an wehenfördernden Mitteln, der Häufigkeit von Analgetikagaben intrapartal sowie bei lokal- und regionalanästhetischen Verfahren. Hier erhielten türkischstämmige Patientinnen und Migrantinnen anderer Herkunft seltener die genannten anästhesiologischen Verfahren, aber häufiger Oxytocin. Das Rooming-in wurde ab 1984 bei den deutschen Erst- und Mehrgebärenden häufiger praktiziert.

Diskussion: In der vorliegenden retrospektiven Analyse von 3 historischen Geburtskohorten lassen sich signifikante Unterschiede in der Betreuung zwischen deutschen Frauen und Migrantinnen erkennen. Hieraus lässt sich eine gewisse Fehl- oder Unterversorgung vermuten. Ebenso scheint bemerkenswert, dass sich dieser Trend über 3 Jahrzehnte trotz parallel gestiegener Mi- 
gration und Akkulturation nicht verändert hat. Nichtsdestotrotz existiert weiterhin ein „research paradox“: Trotz der steigenden Raten existieren aus jüngerer und älterer Zeit keine prospektiven oder systematischen Analysen zu der geburtshilflichen Versorgung von Migrantinnen.

\section{Introduction}

\section{$\nabla$}

In Berlin today more than one out of every four newborns is presumed to have parents with an immigrant background [1]. The constant flow of refugees from Syria, Afghanistan and various north African states into Germany since the summer of 2014 has brought attention to the health-related issues associated with immigration. In recent years various studies have illustrated significant disparities in perinatal care and outcomes between women with and without immigrant background: The incidence and prevalence of preterm birth, rates of low and very low birth weight newborns and the incidence of congenital malformations in particular seem to be increased [2-6].

In Germany issues of immigration in obstetrics have long been marginalised by the scientific community, although in the mid1960s "health-care provision for migrant/guest workers" and associated problems became part of day-to-day hospital routine [7-13]. In a review of the literature on perinatal data of immigrants from 1960 to 1989 , the low number of publications from German-speaking countries and particularly from the Federal Republic of Germany despite the subject's continuing relevance, is notable. Older perinatal data analyses from Germany report contradictory findings: Four out of six studies in the 1970s describe "worse" care in the context of stillbirths; two however report better care compared to that received by German women [7]. These older data and empiric clichés regarding "peculiarities" of labour in immigrants were and often still are generalised or passed on without due reflection. However, to date there are almost no retrospective or prospective longitudinal studies addressing the question of whether progressive acculturation and integration processes in certain immigrant groups in Germany have improved or worsened perinatal outcomes in the decades since the so-called "guest workers" were recruited in the 1960s, nor which factors affect these outcomes. New studies describing and analysing obstetric care in immigrant groups should be conducted, however it is also important to research historical developments as this could shed light on the current situation. This monocentric, retrospective data analysis of three birth cohorts from the 1970s to the 1990s thus attempted to answer the following seven research questions, with German women serving as a comparison in each case:

1. Do immigrant women receive uterine stimulants more often during labour?

2. To what extent did immigrant women receive analgesia during labour?

3. Do immigrant women have instrumental or operative deliveries (VE, forceps, caesarean section) more often?

4. Do immigrant women have more episiotomies and/or high grade perineal tears?

5. Which group of women has a higher preterm birth rate?

6 . Are postpartum haemorrhages $>500 \mathrm{ml}$ more common among immigrant women?

7. How common is rooming-in in the different study groups?

\section{Materials and Methods}

$\nabla$

An analysis of data taken from the birth registers of the municipal Rudolf-Virchow Hospital in Berlin-Wedding was conducted for three decades represented by the arbitrarily chosen years 1974 , 1984 and 1994. Data was anonymously transferred from the birth registers to an Excel table by hand (v.R.R.). A comprehensive plausibility test was performed on a sample of subjects from each birth year (M.D.). The observation period was restricted to the above mentioned years since a review of the birth register revealed almost no immigrant deliveries at the Virchow Hospital in 1964, and extension to the year 2000 did not seem sensible on consideration of recent changes to the treatment/care profile of the Charité's Virchow Hospital site: At the end of 1995 the University Women's Hospital Charlottenburg merged with the Virchow Hospital's obstetrics and gynaecology department, and in 1998 the Virchow Hospital became part of the Charité University Hospital, Berlin (Charité - Universitätsmedizin Berlin). As a result there have been changes in the treatment profile and patient clientele in terms of high risk pregnancies and births.

\section{Exclusions}

For data analysis women were grouped as either primipara or multipara, so that those with missing information on parity had to be excluded from the study. Group allocation according to immigrant background was on the basis of a name analysis (๑ Fig. 1); thus women whose name information was incomplete or illegible in the birth register were also excluded, as were women whose names did not clearly fit into any one of the three subgroups. In addition, we excluded women who had a miscarriage (defined as delivery of a fetus with no signs of life and birth weight under $500 \mathrm{~g}$ ).

\section{Group allocation}

Since grouping of study subjects on the basis of their own immigration experience was not possible, a name analysis was used that was based on an algorithm previously developed for the identification of people of Turkish origin (Spallek et al. 2014 [1]) and adapted to the current study circumstances ( $\bullet$ Fig. 1 ). First names and surnames that were common in multiple study groups were defined as so-called "doublets". Patients whose first and surnames could clearly be assigned to different groups, and those with incomplete name information were excluded from the analysis. Name allocation was performed by two independent experts, one of whom had Turkish immigrant background, and was supervised by a third person.

Study subjects were then grouped as follows: Group 1: German women; group 2: women of Turkish origin; group 3: "immigrants of other origin".

Women with immigrant background were subdivided into a relatively homogeneous group of Turkish origin, and a relatively heterogeneous group of "other" origin, since those of Turkish origin represented the largest group of immigrants overall in the study period, as they also do currently in Berlin. 


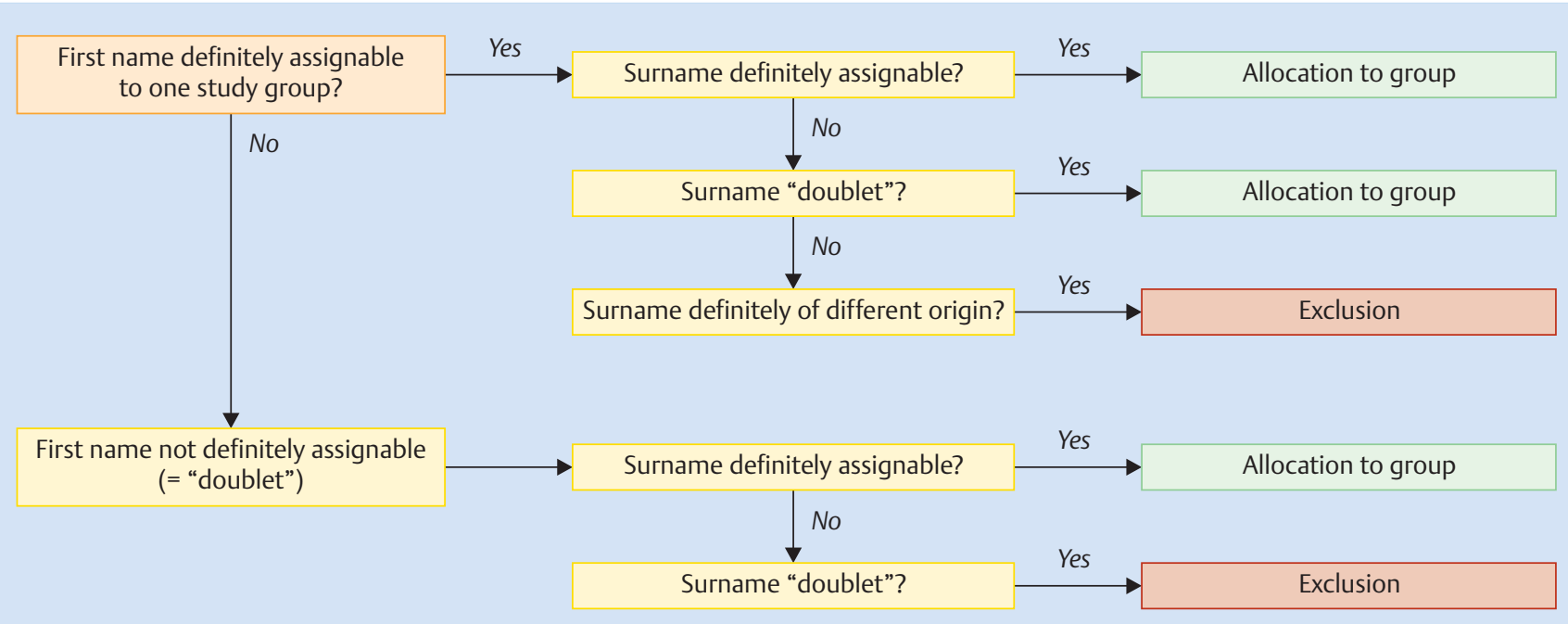

Fig. 1 Name analysis algorithm.

\section{Statistical analysis}

The statistical program SPSS 20.0 was used for the analysis. In a first step the immigrant groups were initially each compared to the group of German women - though not with each other - using Pearson's $X^{2}$ test, since the study parameters were all nominal variables from unrelated samples. Where expected case numbers were $<5$ per cell Fisher's exact test was used. Variables with significant differences on $\mathrm{X}^{2}$ test were then subjected to a binary logistic regression analysis (backward stepwise). The following criteria were included in each regression analysis (reference variables in bold type):

1. Descent/origin (German/Turkish/other)

2. Parity (primiparous/multiparous)

3. Year $(1974 / 1984 / 1994)$

4. Apgar $(\geq 7, \leq 7)$

5. Prematurity $<37+0$ weeks gestational age $(\mathrm{GA})$

6. Stillbirth $>500 \mathrm{~g}$ (miscarriages under $500 \mathrm{~g}$ were excluded)

7. Transfer to neonatal intensive care unit

8. Caesarean section rate (regardless of indication)

9. Rates of episiotomy and grade III/IV perineal tears

10. Rate of postpartum haemorrhage $(>500 \mathrm{ml})$

11. Local and regional anaesthesia; analgesia in labour

12. Paternal presence at delivery and rooming-in

The likelihood ratio test is applied to determine the regression coefficient when using the backward stepwise logistic regression. The value 0.10 was set as the exclusion criterion. The Hosmer-Lemeshow test was used to test the validity of the binary logistic regression model. The significance level was set at $\alpha=0.05$. Model relevance was determined using $\mathrm{R}^{2}$ tests according to Cox \& Snell and Nagelkerke. Odds ratios and 95\% confi- dence intervals were determined for each regression analysis. No adjustment for multiple testing was performed, since the analysis was retrospective.

The study concept of this retrospective analysis was discussed with and approved by the hospital's institutional board. The study was carried out in accordance with the principles of good scientific practice assurance of the Charite - Universitätsmedizin Berlin, and in accordance with data protection requirements.

\section{Results}

A total of 5454 perinatal data sets were documented. Seven patients were excluded due to incomplete name information and a further 298 patients whose names could not be clearly assigned to a single study group were also excluded (dropout rate: $5.6 \%$ ). The analysis results that follow thus apply to a study collective of 5149 births, with 1937 births from the year 1974, 1314 from 1984 and 1898 from the year 1994.

\section{Sociodemographic characteristics and perinatal outcome}

The percentage of patients with immigrant background was initially considerably lower than that of German patients (Germans $60.8 \%$ in 1974 and $63.5 \%$ in 1984). This changed however, and in 1994 immigrants made up well over $50 \%$ of the study population ( Table 1). While the percentage of mothers over 35 years of age remained constant over the study period, the percentage of mothers younger than 24 years of age at the time of childbirth fell in favour of those between 25 and 35 years old ( $\bullet$ Figs. 2 and 3 ).

Table 1 Percentage of patients according to origin for the three study years: 1974, 1984, 1994.

\begin{tabular}{|c|c|c|c|c|c|c|c|}
\hline & \multicolumn{2}{|c|}{ German origin } & \multicolumn{2}{|c|}{ Turkish origin } & \multicolumn{2}{|c|}{ Other origin } & \multirow{2}{*}{$\begin{array}{l}\text { Total } \\
\text { Absolute }\end{array}$} \\
\hline & Absolute & Percentage & Absolute & Percentage & Absolute & Percentage & \\
\hline 1974 & 1178 & $60.8 \%$ & 562 & $29.0 \%$ & 197 & $10.2 \%$ & 1937 \\
\hline 1984 & 834 & $63.5 \%$ & 353 & $26.9 \%$ & 127 & $9.7 \%$ & 1314 \\
\hline 1994 & 729 & $38,4 \%$ & 683 & $36.0 \%$ & 486 & $25.6 \%$ & 1898 \\
\hline Total & 2741 & $532 \%$ & 1598 & $31.0 \%$ & 810 & $15.7 \%$ & - \\
\hline
\end{tabular}



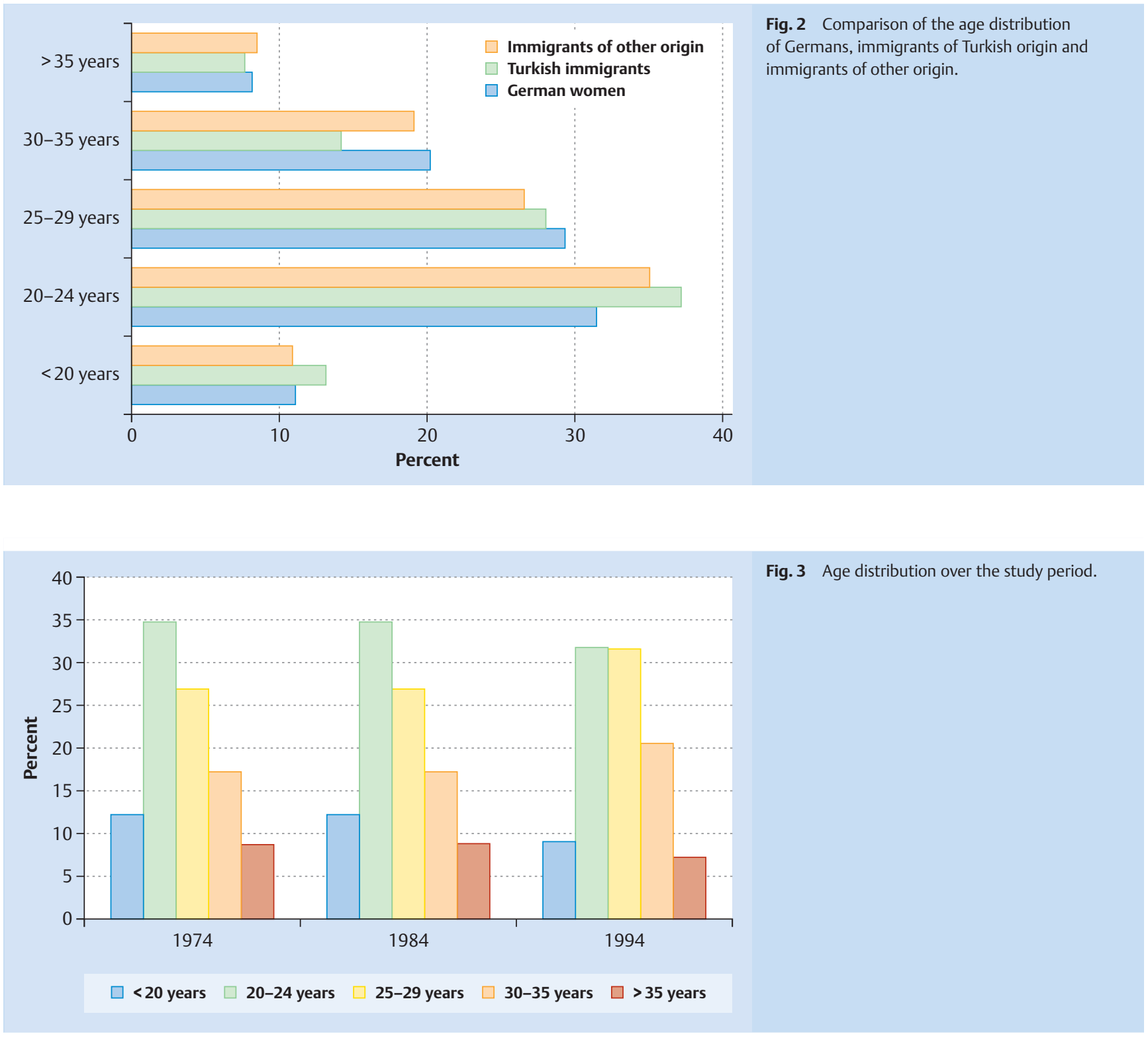

It was not possible to obtain reliable data on obstetric history (abortions, miscarriages, ectopic pregnancies) or general person$\mathrm{al} /$ medical history from the information documented in the birth registers.

Rates of caesarean section, episiotomy, high grade perineal tears and severe postpartum haemorrhage (defined as blood loss $>500 \mathrm{ml}$ ) were not significantly different between Germans, Turkish immigrants or "immigrants of other origin". The rate of preterm birth (defined as before 37/0 weeks gestation) was highest among German women, independent of parity, and lowest among immigrants of Turkish origin. The consecutive logistic regression analysis showed no statistically significant association between immigrant background and prematurity. Parity had no effect on prematurity either.

\section{Disparities in obstetric care}

During the observation period uterine stimulants (labour induction/augmentation agents) were used more often among primipara than multipara. Among all multipara as a group, they were used most often in German women (66.6\%); in contrast among all primiparous women, they were used most often in "immigrants of other origin" (83.6\%). On logistic regression analysis there was no significant difference between Turkish immigrants and Germans ( $\mathrm{p}=0.867$ ). "Immigrants of other origin", however, received uterine stimulants significantly more often (OR 1.287, $\mathrm{p}=0.008$ ).

Independent of parity, over the course of the observation period (comparison of the years 1974 vs. 1984 vs. 1994) a distinct decrease in the use of analgesics in labour was observed, from 84 down to $4.9 \%$, and from 63.2 down to $1.9 \%$. In 1974 German women received analgesics significantly more often than Turkish immigrants ( 68.1 vs. $56.5 \%, \mathrm{p}=0.001$ ); no significant difference was evident on comparison with "immigrants of other origin". In 1994 however, "immigrants of other origin" received analgesics significantly less frequently than Germans (0 vs. 2.9\%). A similar result was shown for the use of local and regional anaesthesia (from 53.6 down to $7.5 \%$ in primipara, and from 25.4 down to $1.4 \%$ in multipara), which were used significantly less in both groups with immigrant background across all three observation years. There were also significant differences for rooming-in: 
Over the whole observation period both Turkish immigrants and "immigrants of other origin" were significantly less likely than Germans to be accommodated in the same room as their children, with odds ratios of 0.142 and 0.195 respectively ( $\mathrm{p}$ in both cases $<0.001$ ).

\section{Discussion}

$\nabla$

Reports on "births among foreign nationals" were published in Germany for the first time in the mid-1960s, bringing language and communication problems and their possible adverse effects on labour and obstetric outcomes to the attention of clinicians $[11,12]$. Studies from the late 1970 s, which were linked to the introduction of national perinatal data recording, formed the basis of discussions on the subject in the Federal Republic of Germany well into the 1990s. Based on data from the greater Hannover area, Oeter et al. (1979), for example, found that social factors such as nationality were significantly associated with perinatal mortality, children of non-German origin being negatively affected, and that transfer to children's hospital services occurred significantly more often among newborns of foreign/immigrant mothers [14]. This is in complete contrast to the so-called Mexican paradox, which is discussed in a US American publication: Despite having numerous risk factors (lower education level, worse medical care, lower acculturation level) immigrant women from Latin America have more favourable pregnancy and labour outcomes and a lower incidence of perinatal complications than their "white" US American counterparts [15]. Positive protective influences of the informal, familial network of pregnancy support were seen as a possible explanation. Whether such influences from acculturation and integration processes are present/detectable for immigrants in Germany too, has not been systematically studied to date. When the available data is considered, a "research paradox" is evident: The number of studies and the state of scientific knowledge remain unsatisfactory, particularly in Germany, despite the fact that since the mid-1960s immigration issues have become increasingly prevalent and are increasingly encountered in the hospital and practice health care sectors. The results of the current study, which documents a development over three decades, at least provide evidence of disparities in perinatal care in the past between German women, immigrants of Turkish origin and of "other" origin. The parameters reflecting direct, personal care and interaction between medical staff and patients especially show significant differences, suggesting possible deficits in medical care: Immigrants of Turkish origin received epidural anaesthesia less often than immigrants of other origin or German patients. Labour augmentation agents/uterine stimulants were also used less often.

Even though similar results were found by Rizzi et al. [16] for caesarean section rate, and by Rust et al. [17] and Glance et al. [18] for use of epidural anaesthesia in labour in Italy and the USA respectively, the generalisability of our study results is limited by the retrospective nature of data collection, and by the fact that sociodemographic information was missing. Accommodation of mother and child together in hospital, so-called "rooming-in", was also significantly less common among immigrants. Similar results can be found in the international literature. Walsh et al. [19] report that immigrant women received an epidural in labour significantly less frequently. In 2004 Yoong et al. published a comparative study finding a lower epidural anaesthesia rate among Kosovo Albanians in Great Britain who had little or no
English language proficiency [23]. Rust et al. [17] analysed the deliveries of almost 30000 women in the USA and reported an epidural anaesthesia rate among African American women, Hispanic and Asian women significantly lower than that for non-Hispanic "white" women. Limiting factors were, however, that it remained unknown whether epidural anaesthesia was offered by medical staff or requested by labouring women, and whether logistical or objective reasons could have explained the findings. In our retrospective analysis there was no difference in caesarean section rates. This result is however contrary to internationally published evidence. In a comparison of matched pairs, Rizzo et al. (2004) found that the method of delivery "planned caesarean" was more common among native Italian women than local immigrants. A 2009 prospective analysis of birth data from approx. 1800 children born in Austria only showed a significant difference for one subgroup, namely immigrants of Turkish origin, who had fewer primary caesarean sections and more vaginal deliveries compared to non-immigrants [20]. Our data nevertheless agree with other data available from Germany, which have not shown any difference in caesarean section rates [21].

In summary, this relatively comprehensive, retrospective perinatal data analysis of three historical birth cohorts has identified disparities that at least confirm that patients with immigrant background receive different care, and are suggestive of deficits in care. The study also highlights that the situation has not changed measurably over the course of three decades despite increasing immigration and acculturation in Germany. With this background, the question remains as to why no other systematic or prospective analyses of any kind have yet been published in Germany, for example of the likes of those published in a neighbouring European country, the Netherlands: E.g. the Generation R Study from the greater Rotterdam area investigated the effects of ethnicity on pregnancy, birth and child development in over 6000 women [22].

Although we have only conducted a historical review, with retrospective data analyses, these data nevertheless provide important insights towards an objective, evidence-based debate on the obstetric care of immigrant women. No recent data on the subject exist: To find studies similar to this review an extensive literature search, back to the 1960s and 1970s, is necessary $[9,13]$.

\section{Conflict of Interest}

$\nabla$

None.

\section{References}

1 Spallek J, Lehnhardt J, Reeske A et al. Perinatal outcomes of immigrant women of Turkish, Middle Eastern and North African origin in Berlin, Germany: a comparison of two time periods. Arch Gynecol Obstet 2014; 289: 505-512

2 Malin M, Gissler M. Maternal care and birth outcomes among ethnic minority women in Finland. BMC Public Health 2009; 9: 84

3 Kelly Y, Panico L, Bartley $M$ et al. Why does birthweight vary among ethnic groups in the UK? Findings from the Millennium Cohort Study. J Public Health 2009; 31: 131-137

4 Troe EJ, Raat H, Jaddoe VW et al. Explaining differences in birthweight between ethnic populations. The Generation R Study. BJOG 2007; 114: $1557-1565$

5 Stoltenberg C, Magnus P, Lie RT et al. Birth defects and parental consanguinity in Norway. Am J Epidemiol 1997; 145: 439-448

6 Alderliesten ME, Vrijkotte TG, van der Wal MF et al. Late start of antenatal care among ethnic minorities in a large cohort of pregnant women. BJOG 2007; 114: 1232-1239 
7 David M, von Hofen-Hohloch J, Ebert AD. Die gebärende „Gastarbeiterin“ der 1960er- bis 1980er-Jahre - eine kurze medizinhistorische Literaturübersicht. Geburtsh Frauenheilk 2013; 73: 1191-1193

8 Schliemann F, Schliemann G. Über den Geburtsverlauf bei Ausländerinnen. Geburtsh Frauenheilk 1975; 35: 210-217

9 Schultze-Naumberg $R$, Scholtes G. Entbindungen bei Ausländerinnen. Med Klin 1976; 71: 63-67

10 Strobel E. Beteiligung der Gastarbeiterinnen an der Schwangerenvorsorge. Fortschr Med 1975; 28: 1301-1308

11 Saurwein A. Entbindung bei Ausländerinnen, zugleich ein Beitrag zur Frequenz und Indikationsstellung der abdominalen Schnittentbindung. Geburtsh Frauenheilk 1969; 29: 728-734

12 Rimbach E. Schwangerschaften und Geburt bei Ausländerinnen. Archiv für Gynäkologie 1967; 204: 293-295

13 Loew D, Schrank P. Bericht über 7000 Geburten in einem mittleren Krankenhaus unter Berücksichtigung der Geburtsverläufe bei Ausländerinnen. Zentralbl Gynäkol 1966; 88: 23-31

14 Oeter K, Collatz J, Hecker H et al. Werden die präventiven Möglichkeiten der Schwangerenvorsorge ausreichend genutzt? Gynäkologe 1979; 12: 164-174

15 Hoggatt KJ, Flores M, Solorio S et al. The "Latina Epidemiologic Paradox" revisited: the role of birthplace and acculturation in predicting infant low birth weight for Latinas in Los Angeles, CA. J Immigr Minor Health 2012; 14: 875-884
16 Rizzo N, Ciardelli V, Colleoni GG et al. Delivery and immigration: the experience of an Italian hospital. Eur J Obstet Gynecol Reprod Biol 2004; 116: $170-172$

17 Rust G, Nembhard WN, Nichols $M$ et al. Racial and ethnic disparities in the provision of epidural analgesia to Georgia Medicaid beneficiaries during labor and delivery. Am J Obstet Gynecol 2004; 191: 456-462

18 Glance L, Wissler R, Glantz C et al. Racial differences in the use of epidural analgesia for labor. Anesthesiology 2007; 106: 19-25, discussion 6-8

19 Walsh J, Robson M, Foley M. The influence of ethnicity on caesarean section rates in the home of active management of labour [abstract]. Int J Gynecol Obstet 2009; 107: S373-S374

20 Oberaigner W, Leitner H, Oberaigner K et al. Migrants and obstetrics in Austria-applying a new questionnaire shows differences in obstetric care and outcome. Wien Klin Wochenschr 2013; 125: 34-40

21 David M, Borde T, Brenne S et al. Comparison of perinatal data of immigrant women of Turkish origin and German women - results of a prospective study in Berlin. Geburtsh Frauenheilk 2014; 74: 441-448

22 Troe EJ, Raat H, Jaddoe VW et al. Explaining differences in birthweight between ethnic populations. The Generation R Study. BJOG 2007; 114: $1557-1565$

23 Yoong W, Wagley A, Fong C et al. Obstetric performance of ethnic Kosovo Albanian asylum seekers in London: a case-control study. J Obstet Gynaecol 2004; 24: 510-512 